More Information

\title{
Contemporary American stupidity
}

\section{James F Welles*}

Ph.D., USA

The American character is filled with contradictions and paradoxes [1], so it is understandable that, being susceptible to the imperfections, weakness and evils afflicting all peoples [2], it features its share and many types of injustices and stupidity.

Injustice: Without a doubt, the worst single violation of civil rights of American citizens and abuse of the Constitution was the detention of Japanese-Americans during World War II [3]. After acknowledging the total absence of any provocation whatsoever, West Coast army commander General John DeWitt indulged in stupefying illogic when declaring, "The very fact that no sabotage has taken place is disturbing and confirming indication that such action will be taken" [4]-a non-Pavlovian reaction to the absence of a stimulus.

In Korematsu v. United States, one of the worst decisions in Supreme Court history, former Klansman, Justice Hugo Black tried to explain away the truth. "Our task would be simple .... were this a case involving the imprisonment of a loyal citizen in a concentration camp because of racial prejudice", he wrote, which was exactly what the case was-a loyal citizen and 127,000 others [5]-was imprisoned on the assumption that his race/ethnicity made him security risk not because of anything he had done but because of who or, worse yet, what he was. So, ironically, here is an accurate verbalization of reality blithely ignored by its writer. With no apparent cognitive dissonance whatsoever, he proceeded to rationalize the detention of a disfavored racial minority member behind barbed wire and machine gun towers because when his colleagues scrutinized the operative Executive Order 9066 for racial discrimination, they found no explicit mention of race or ethnicity. To his credit, rights-lover but efficient J. Edgar Hoover informed Attorney General Biddle that mass evacuations were not necessary because all security risks had been rounded up by the FBI, awhich, within two hours of the attack on Pearl Harbor, began taking Japanese leaders into custody, and, as panic spread along the west coast, government officials searched houses where aliens lived for pictures or documents which might suggest loyalty Japan [6]. Biddle duly informed the president of Hoover's message but to no effect [7]. Political fear triumphed over law [8] and that ineffectual document, the Constitution, which apparently can be suspended without even a vote of Congress in wartime [9].

\author{
*Address for Correspondence: James $\mathrm{F}$ \\ Welles, Ph.D., USA, \\ Email: JWelles103@aol.com
}

Submitted: 21 April 2020

Approved: 15 May 2020

Published: 18 May 2020

How to cite this article: Welles JF. Contemporary American stupidity. Insights Biol Med. 2020; 4: 009-022.

DOI: 10.29328/journal.ibm.1001017

Copyright: @ 2020 Welles JF. This is an open access article distributed under the Creative Commons Attribution License, which permits unrestricted use, distribution, and reproduction in any medium, provided the original work is properly cited.

Check for updates

(1)

OPEN ACCESS

Thus, this episode proved the impotency of the Constitution as a guarantor of rights [10], which are indulgences granted by government authorities for the moment [11]. As grants, they are subject to revocation whenever it suits those in power to exercise this totally illegal and unconstitutional option. Further, when there is an abuse of authority, the courts are as likely to protect the villains as the victims. Finally, it proved the American dream of assimilation was a failed myth [12], but, in a rush $(0$ to admit its mistake, forty years later the government apologized and made reparations of $\$ 1.6$ billion to the survivors of the incarceration by their racist government [13].

The experience of those who at the time challenged the legality of the incarceration program calls attention to another weakness in our judicial system: someone has to break a law, and be punished before being able to get a ruling as to the legality of the law. E.g.,-from another domain, Rosa Parks had to get arrested in a bus in order to get the laws on segregation into the court system. There really should be a way to have a prior ruling on a bill's constitutionality as it is on the way to

${ }^{\text {a }}$ Forty years after the fact Mr. Korematsu sought to have his case voided retroactively. The court found the Justice Department and the Army had distorted the record to make it appear there had been a legitimate security risk when there was none. Congress granted $\$ 20,000$ to each detainee. (Feldman.) Only 40\% of the detainees were born in Japan; the others were first and second generation Americans. In addition, 3,000 people of Italian descent locked up as were 11,000 Germans. Ironically, some of these were Jews who had fled from Hitler's Germany, only to be imprisoned in the US. A further irony is that the rights for which we were fighting were suspended while we were fighting for them: They might be considered "Fair weather rights". Btw, Italians in Britain were detained during the war. (Rooney. 204.) 
becoming a law-e.g., have a ruling on constitutionality before a bill is submitted to the president for signature.

American political confusion is compounded by the schizoid attitude of citizens toward government and governmental programs. In the abstract, as a generalization, Americans intuitively dislike if not fear big government. On the other hand, they tend to favor specific programs like social security, unemployment compensation, Medicare, etc [14]. So, they want the programs without a big over organized bureaucracy and prefer both without the higher taxes to pay for them or the inflation which accompanies deficit spending needed to enforce the laws in and of the courts.

Courts really are show places for the legal process. They are invariably pretentious, ritualized and somber. Upon entering a court, one gets the immediate impression that something important must go on in such a setting. The impression is correct: justice is dispensed with. A killer is set free because some functionary dotted a "T" or crossed an eye. A defendant is railroaded because the judge or prosecutor is up for reelection and needs to toughen his/her image. The bottom line is not justice but the belief in justice, but on what is that functionless belief based? If the government can show that a law is "rationally related or legitimate" in serving its purposes ... even if it is idiotic", the courts will likely grant it deference. Many judges believe that matter is the purview of the legislators, and they are under no obligation to change a law to correspond with the facts or knowledge [15].

The facts are that for every 1,000 major felonies, 17 perpetrators go to jail but for what? In pretrial maneuvering, armed robbery is watered down to simple robbery, and rape is plea-bargained down to assault with a friendly weapon. Further, in 1983, while forty-two percent of those sent to state prisons were on parole for prior convictions, 55,000 criminals were set free on legal technicalities [16]. In 1991, only $21 \%$ of people who committed major crimes were arrested. Only $17 \%$ of murders, $5 \%$ of rapes and $3 \%$ of robbery, assault, burglary and auto theft lead to prison sentences [17]. These are facts upon which our belief in the legal system is not based, and it could be considered a gold-plated invitation to felons to do their thing-and it is ${ }^{\mathrm{b}}$.

The Economy: Along with our belief in Constitutional government, we believe in the ever inflating dollar. It is curious to note that the dollar is impossible to define with accuracy and validity. At best, it is one of those green pieces of paper in your wallet or pocketbook. At worst, it is a figment of a collective imagination which makes the economy one of

${ }^{b}$ As Lenny Bruce noted, the "Halls of Justice" is an appropriate term because the only place you get justice is in the halls. (McWilliams. 206) On the other hand Josiah Quincy ca 1800 noted legislative matters were settled somewhere other than in the halls of Congress. (Remini.) Likewise real history consisted of the secret stories and covert conversations that occurred in corridors and behind closed doors, where the real decisions were made the real arguments hammered out and real power exercised. (Ellis, J. 1998. p. 304.) the newer permanent, floating con games in America's tawdry history of scams. Unlike the "Commodity money" silver certificates, which at least said they were redeemable in hard metal, today's dollar bill is not worth the paper it is printed on in any literal or legal sense. As "Fiat currency" [18], it has value only because everyone believes it does and willingly accepts it accordingly. Indeed, we now have "Virtual dollars" which appear only as symbols on a 'puter screen. Hence, our national motto really should be changed from "In God we trust" to "In the dollar-or whatever it is-we believe" [19].

Of course, God seems to be doing her best to separate Himself from the country, and who can blame it. The Constitution means anything/nothing, and the dollar is a joke on paper. It is only our inability to perceive and act on these facts that holds America together and keeps it going. Apparently, no fundamental facts of life, no basic knowledge of reality, no logical analysis of the establishment can shake America's faith in the system, and it is precisely this faith which permits our national nonsense to continue.

The key to understanding the incomprehensible is that we believe in capitalism. Just why we do is a mystery. Perhaps it is because we do not perceive the estates of the rich in a cause/ effect juxtaposition to urban slums. Perhaps it is because the ritual of buying and selling in the market place sustains the faith in the system. Most probably, it is because most of us cannot grasp the idea that "Capitalism" is just a word which has next to nothing to do with the workings of the corporate economy.

The fact is that as an economically overdeveloped nation, America distributes poverty and misery via a politically regulated system of tribute and taxation [20]. Of course, the role of free enterprise in the economy of things is essentially negligible. In fact, the major contribution of the corner shoeshine man and local farm stand operator is not economic but psychological-justifying the continuation of capitalistic rhetoric in a world of collective regulation by mega corporations and governments. At municipal and state levels, public utilities which are not socialistically owned by government are fascistically regulated by it. However, regulation of private enterprise is most common in Washington, where federal officials engage in back-scratching interactions with the special interest groups they are allegedly controlling. An example of this is the ridiculous if not insulting record of the Consumer Product Safety Commission, which under "W" pretended to regulate foreign-made products flooding our markets. The kindest thing that can be said is that it should be renamed "The Corporate Profit Safety Commission"c, as it does everything it can to maximize profits for our own companies which endanger the health and welfare of our gullible citizens [21].

As bad as such regulation is for the economy in general, "De-regulation" can lead to some unexpected problems in some areas as it did in banking ${ }^{\mathrm{d}}$. For more than fifty years, 
banks hid in an artificially sheltered, unnaturally conservative environment with legal protection from competition while Federal Deposit Insurance Corporation guaranteed the survival of even the most poorly managed organizations. Stagnation replaced enterprise, and sheer incompetence became commonplace if not rewarded. With the opening up of competition among financial institutions in the 1980's, banks sank money into a number of black holes-soil, farmland, the Third World, commercial real estate and leveraged buyouts. In the 1990's, the absence of a functional schema proved disastrous because with no guiding cognitive model based on experience to guide them, bankers proved unable to learn from successive fiascos, and only a few CEOs were canned for mismanagement [22]. Finally, greedy bankers raised adjustable-rate mortgages so high so fast that cash-strapped home owners in 2008 had to default, ushering in a major recession.

On the labor scene, strong unions were thought to be a counterpoise to greedy business but in fact joined with mismanagement and big government to bamboozle the American worker. To the extent that unions obtained more pay for less work, they created unemployment and caused inflation. It may have been all well and good for an assembly line worker in Detroit to make $\$ 23$ per hour-until the Japanese flooded the market with better-made, cheaper cars. In 1984 the government protected and the consumer subsidized (to the tune of $\$ 600 /$ car) management's ineptitude and labor's greed ${ }^{\text {e }}$ Presumably, national interests were served by the protection of obsolete marketing and manufacturing strategies and the employment of workers who prevented the economic production of competitive, quality cars.

\section{Society}

Another peculiar aspect of the American labor scene is the irrelevance of selective criteria used when people try to join the work force. Traditionally, America was a caste society covered over with egalitarian maxims and morals and an incongruous ideology of racial superiority which sanctioned the system [23] while it inhibited random interactions among equal people. Whites derived their social eminence from their control of the economy and, through that, the political system, although all these are eroding as the moral imperative of social justice inherent in democratic rhetoric is realized.

'This represents 43's basic policy of using the government to promote special business interests at the expense of the people and democracy.

${ }^{d}$ The argument for deregulating banks is one of the most bassakwards wards ever made. The pitch was that since there had been no depression in the past sixty years, the regulations were no longer needed. Someone was dumb enough to buy into this, so the regs were removed, and we got the recession in 2008. Supreme Court Justice Ginsburg put it well: It was like throwing away an umbrella during a shower because you were not getting wet. (Dyson, M. Tears We Cannot Stop. 2017. p. 81.)

${ }^{e}$ Update: in 2008 workers got \$71/hour in wages and benefits, and the industry received a $\$ 15$ billion bailout loan from the indebted government Happily, we assume, it saved the industry.
While it was stupid to repress talent and stifle ability in the past, it is inexcusable that we still continue to do so. Nevertheless, we continue our tradition of inefficiency by demanding the work force reflect not the distribution of ability in it but the racial composition of society in general. To this end, "Race norming"-rigging employment aptitude tests to favor minorities-has been used by thirty-eight states at the behest of the Labor Department in order to enhance the chances of blacks and Hispanics of landing jobs [24] for which they may be less qualified than other test takers.

If the legality and sagacity of that policy are at best dubious, one certainty in the American labor market is that the individual worker has become an anachronism. In the superficial and entertaining world of professional sports, performers may be rewarded for if not beyond proficiency and technical expertise. However, in the general work force, non-performance criteria determine hiring (race and sex) and promotion (seniority), so mediocrity can be maintained by emphasis on factors totally irrelevant to job efficiency. In fact, a worker's main job is not to accomplish a task but to conform to and fit into the group's value system.

Although it is a secondary consideration, to the extent that a job requires an employee to do something, workers must have some basic ability, acquired through training, to handle machinery or computers. This means that some people are going to be denied jobs because they are unqualified. If such people are unwilling to accept menial positions of employment, society will probably find a place for them on welfare. We already have third generation deadbeats who expect the country to provide not an opportunity to earn a decent living but the decent living itself-as if a good income is an economic right.

In general, we now face the problem that any governmental program, policy or plan of action may quickly become maladaptive [25]. Traditional values may be irrelevant to the young, and old definitions may not be challenged so much as ignored. The extended family has made way for the distended state, which is being computerized as it assumes its new, illconceived roles. This is rather trying for anyone clinging to presumably fundamental, eternal values in an ever evolving culture. Belief in God has been partially displaced by a belief in the state, and now the humanistic tradition is giving way to beliefs in secular organizations which are struggling to strangling themselves in red tape.

For example, the belief in federal welfare has led to government funding of urban ghettos, and as a contemporary case study of what a benign if not bungling bureaucracy cannot accomplish, our city slums compare favorably with the Indian reservations of the last century. The major difference is that reservations are legally defined areas, whereas ghettos are extralegal territories. The major similarity is that both may be characterized as tending toward the same omega point 
of economic, cultural and spiritual genocide. In both cases, emphasis on the level of funding and degree of sympathy misses the subtlety that providing people with food, shelter and trinkets falls short of helping them become self-sufficient [26].

Traditionally, black culture in America was basically a tension-reducing strategy promoted by the Associated Press and Christian churches [27. Fundamental Christian rituals provided temporary and meaningless emotional release from the oppressive white world. However, for all the singing, shouting and hand clapping, heavenly rewards were to be granted only those who accepted their downtrodden condition here on earth [28]. As debilitating as resignation was, it was the best coping technique for people who were systematically denied opportunities to acquire and use skills for worldly advancement. Eventually, black leaders realized that power not patience prevailed -that rights were not granted (i.e., they were very alienable); they had to be taken to be won, and only a fool thought otherwise [29]. Now, blacks are granted opportunities to use skills even when someone else is better qualified. This perversion of the Constitutional mandate of equal protection of the laws undercuts the great social myth of contemporary America that poor minority groups are being helped by legitimate policies of the courts, charities and liberals who worship at the altered altar of "Civil rights". The concern of many people to help those in need is humane as well as laudable, but just how effective have the means adopted been in helping the needy escape the slovenly despair of the ghettos? Are our slums any smaller or more bearable for all the hot lunches that have been pointed in their direction? For all the good intentions of the establishment to beguile those in the slums to accept whatever is granted them, most children of the ghettos know that the easiest way up and out is through crime. This is the saddest indictment that can be made of our urban policy.

As adjuncts of urban policy, social problems begged for sensible, reasonable solutions. For centuries, members of racial minority groups were systematically denied opportunities offered to and enjoyed by the white establishment. The reality of their bad housing, inferior educational facilities and limited possibilities for employment went unrecognized by a system set up to ignore such conditions [30]. Gradually, however, the clear injustice of this arrangement led to protests, marches, demonstrations and riots which eventually induced real adjustments in the direction of ideals espoused by liberalsas voices incarnate of God, The Great Hermaphroditic Social Worker- but ignored for as long as possible by the conservative powerful and mighty.

Generally, the prevailing social ideal of the contemporary American establishment was that the poor minority group member could be integrated into a completely homogenized society and would join the majority if given the opportunity to do so. This provided the ideological basis for court decisions, humanitarian activities, selective appeals to civil rights, preferential consideration in admission to colleges and discriminatory alterations of qualifications for employment and promotion [31]. Integration is all the rage, and it is so commonly understood as a social goal that it is hardly ever even mentioned amidst the rhetoric in 2016 about "Affirmative Action" [32], "Civil rights", "Women's lib", "Diversity" and "Discrimination". The abuse of this last term in our language is most revealing about prevailing ambiguity in defining acceptable means of achieving an implicit and generally laudable end.

Although it is a synonym for "Distinguishing", "Discrimination" has been equated, through long historical association, with "Segregation" [33]. What we had in the field of "Civil wrongs" was a rash of Affirmative Action laws requiring discrimination according to the color of one's skin rather than the content of his/her character as a means of achieving integration. Legitimate efforts to end racial discrimination "Against" were converted into reverse discrimination "For" by the judicial doctrine of "Disparate impact", which meant the racial composition of a workforce had to reflect the local employment pool or else. The required cognitive dissonant remedy was the adoption of quotas which were hardly hidden by such semantic disguises such as "Goals", "Timetables" and "Verifiable measurements" [34].

Racial discrimination was supposed to have become legally unfashionable in the mid-1960's [35], but a decade later those passionately committed to integrating society took over the means of their historic adversaries and required race to be considered in hiring and promotional procedures. In the pursuit of "Equality", the Constitutional mandate of "Equal protection of the law" has been subverted, and contrary to a ruling of the Supreme Court [36], in the cause of diversity [37], minority groups have become special favorites of laws which have become means for compensating them for past experiences and current conditions. In 1985, this approach was made explicit when two members of the U.S. Commission on Civil Rights wrote "Civil rights laws were not passed to give civil rights protection to all Americans" [38]. They were presumably passed to compensate members of some groups for their minoritihood, which officially was not supposed to matter anyway.

In a related extralegal, political matter, the Democratic Party dodged cultural bullets by showing deference to the alphabet and language. At the party convention in Miami in 1972 , the roll was called at random so as not to discriminate on the basis of alphabeticalness [39]. Further, party leaders wanted to promote diversity so a commission established quotas by the handy expedient of not using the word "Quota"

${ }^{\mathrm{f}}$ Compliance was another matter. At a Senate hearing, Johns Hopkins University produced a $65 \mathrm{lb}$. stack of documents 2.5 feet high it needed to comply with federal Affirmative Action regulations. (Hayward. 2009. 222.) All this to promote state sponsored racial discrimination, which is supposed to be taboo. 
[40]. Having quotas was $\mathrm{OK}$, but labeling them correctly as "Quotas" was not".

Labels aside, somewhere along the way, the general idea of equal opportunity morphed in the minds of some into the idea of equal results, and individual rights were transformed into group entitlements [41]. The arrogant commitment of government to force this ideal upon the Land of the Free led to a white backlash [42], against the self-contradictory omega point of Affirmative Action programs best summed up in the oxymoronic if unspoken slogans: "End racism! Hire Blacks!"; "End sexism! Hire women!" The backlash took formal shape in Chief Justice Roberts' opinion in 2007 regarding racial discrimination in the cause of integration in schools in Louisville and Seattle with his brilliant if widely ignored insight, "The way to stop discrimination on the basis of race is to stop discriminating on the basis of race" [43].

In a backlash to the backlash, liberal Justice Breyer wrote in both anger and anguish that "....efforts to continue racial segregation are constitutionally indistinguishable from efforts to achieve racial integration [44], which is absolutely true. Racial discrimination can be used for either end: segregation or integration, and changing the end does not justify or dejustify the means. Anyone committed to ending racism would embrace a race neutral, color-blind Constitution, but those pushing for integration were not ready for that yet.

The ideological imperative which demands integration is in turn based on environmentalism as the unstated, unofficial politically erect assumption of the liberal establishment. A corollary is that education is the way to improve society, despite all the failures and shortcomings of public school systems. When necessary, variables other than race (i.e., broken homes, bad nutrition, etc.) are used to save the environmental/educational schema by serving as possible explanations for the poor learning abilities of some minority groups-Orientals ${ }^{\mathrm{h}}$, with their strong family ties, being the notable, somewhat embarrassing exception.

This platonic insistence on theoretical support for a desired policy is actually a betrayal of the liberal tradition, one of the original hallmarks of which was an examination of all aspects of an issue so as to reach the fairest, overall conclusion. However, our mental life is currently so dominated by the democratic,

${ }^{9}$ To Democrats at the time, "Patriotism" was a code word for intolerance, war and deception. (White. 1973.291.) In 1985, the NAACP denounced the Department of Injustice for hiding behind "Goody-good words" like "Equity, fairness and justice". (Hayward 2009. 409) Honesty anyone?

${ }^{h}$ The superiority of Orientals in academics and economic affairs suggests that race and/or a tight-knit family structure may be the key to success, but liberals are clearly ideologically predisposed to favor the latter rather than the former. (Sowell. 2013.) In fact, the superiority of hard working Asians was such an embarrassment to devotees of Affirmative Action that SAT math test results of Chinese and Japanese American students had to be mixed in with those of Polynesians, Hawaiians, Vietnamese and Samoans to create "Pacific Islanders and Asians", whose test results approximated those of whites. (Sowell. 2005. 175.) subjective, relativistic, romantic acceptance of all ideas as being equally good based on a common, psychologically correct commitment to make everyone feel good that we do not discern right from wrong [45], or better from worsej. To confuse matters further, this mentality was justly condemned in the 1870's by the know-it-all Episcopal Church, when minister Edward Eggleston was forced to abandon his humanitarian "Church of the Christian Endeavor" in Brooklyn, NY (USA) because most people regarded it as a "Church of the Holy Ambiguity" which "Believes nothing, teaches nothing, has no opinions and admits all possible opinions as to the truth and falsehood of Christ's Gospel and way of salvation" [46]. So, being open-minded is unacceptable to those who know they have THE answer.

Presidents are known for the words they define: $\mathrm{W}$ defined "Torture"; Clinton defined "Is"; Obama defined "Hostilities" (Stone and Kuznick. 568.), and Trump defined "Wall”.

As regrettable as this is, there is an equally unfortunate flip-side to this attitude. To deal with a problem threatening to its way of life, the government condoned water boarding and torturing "Detainees" at Gitmo and elsewhere in the CIA's penal archipelago. The questions then arise: just what is "Our way of life?" and, "Is it worth defending?" If it is "Can we do it in a manner cognitively consistent with itself?"

The answer led to the unfortunate absurdity that some leaders in our intellectual community may not believe in even the idea of truth. Everyone can gather data, and all opinions are equally valid so if $99.9 \%$ of geographers believe the earth is round and the rest think it flat, both views are to be given equal consideration. Ironically, in our cultural life, people who talk are presumed to be saying something (just as musicians who play a lot of discordant notes and artists who splash paint around must be expressing something meaningful), but anyone who makes an informed, deliberate, specific assertion (e.g., 2+2=4) is anathema because that breaks the taboo against implying someone else's position might be wrongk.

Contemporary liberals are no longer concerned with objective inquiry or a composite of subjective investigations. Indeed, on some college campuses, freedom of speech has been sacrificed to culturally correct orthodoxy. Discussion of many compelling social issues is thus restricted, unless it is based on

${ }^{\mathrm{i}}$ Even to the point that people cannot candidly discuss problems so as to find common sense solutions to them. (Webb. 18.)

If people are known by the company they keep (Cervantes), the macho, heroic Cheney/Bush administration will be remembered as the 21st century American immoral equivalents of the Spanish Inquisition and Khmer Rouge, who water boarded hapless souls in the righteous pursuit of information of dubious value. (Huffington. 224.).

${ }^{\mathrm{k}}$ The shape of the earth provides an excellent example of refinement in scientific models. The Greeks knew the earth is a sphere. Explorers later found it is spheroid-bulging at the equator. Satellite measurement shows it to be an asymmetrical oblique spheroid with the southern hemis- phere slightly larger than the northern. (Novella. 106.) 
the deconstructionist assumption that there is no hierarchy of values. Worse yet, leftist have elevated intellectual dishonesty to the status of moral virtue and often refuse even to consider a discussion of socially sensitive issue like race and behavior [47] unless it is predirected toward confirming the relativist conclusion that all groups of people are subjectively equal in abilities [48]. The corollary is to make a virtue of diversity even at the expense of competence if not excellence.

Such a discussion might begin with the fact that the lower classes breed more efficiently than the middle and upper classes [49]. This is a good strategy for keeping the lower classes low, as they must divide their meager resources among more people. However, it gives a genetic advantage to carriers of cultural phenomena like illiteracy, ignorance and poverty, since the best educated, well-to-do people willingly reduce their contribution to the gene pool of each succeeding generation in order to maintain their position of vaunted cultural superiority. Of course, the idea of employing birth control as a means of promoting cultural equality is lost on those who perceive reduced reproduction as a plot to suppress racial minorities, while any form of eugenics-even a policy which would forbid reproduction by certified morons, the criminally insane and lawyers-is basically unthinkable [50].

Foreign policy: If it is demoralizing to look inward at our domestic idiocy, it is equally disconcerting to note that our foreign policy for forty-five years after WWII was stuck like a broken record in a rut [51] of rhodophobic [52] negativity. Over and over again, we were anti-Communist, anti-Communist, anti-Communist. This took its most explicit form in the pronouncements of President Ronald Reagan, who delighted in denouncing the Evil Empire [53]. If this attitude was justifiable, it was partly because no American with an ounce of cognitive integrity could make positive pronouncements abroad about the corruption, drugs and crime in his country. Our commonplace pronouncements about promoting democracy were undercut by the fact that we would remove any leftist governments elected by voters in any non-Communist country: basically, such electorates were free to (s) elect anyone of whom we approved [54]. More generally, regardless of how governments come to power, those we support tend to stay in power; those we do not do not [55]. If we were once the hope of the world, we betrayed that hope and now just struggled along like any other country trying to get on with those who depend on us and those who just have to tolerate us.

As for those perceived as our national enemy, the Soviets always called for an end to the Cold War because they defined it as attacks on or criticism of Communist states by the West. What they did to the Western bloc or anyone else was covered over and sanctified by the term "Peaceful coexistence" [56]. They eventually comprehended that we really did not want to beat them in a war. Of course, we wanted even less to lose to them, but our general posture toward the former Soviet Union was quite consistently defensive: we were very much oriented just toward containment and holding the line. Our stance was somewhat murkified by the difference between the ways different pols viewed the Cold War: liberals viewed it in the context of 1914-that the biggest danger lay in miscalculation or miscommunication leading to WWIII, while conservatives viewed it in the context of 1938 -that the biggest danger lay in craven, Munich-like appeasement leading to WWIII [57]. During the Cold War our government routinely tinkered with and in foreign elections, assisted or acquiesced in coups d'état which overthrew democratically elected officials, producing repressive, corrupt regimes which violated human rights and often ran drugs: but they were not Communist governments, which is all that really mattered [58].

With the end of the Cold War, it was time to reverse the tradition of finding better ways to kill our enemies and develop better ways to live with them [59]. Fortunately for everyone, the time has past when we had to have not only the weapons necessary but also the insane willingness to use them to produce the ultimate peace. We can now stop pouring hundreds of billions of dollars into weapons systems we will not have time to use unless it is the last thing we ever do. We can alter the traditional picture of the incomparable stupidity of the arms race, when the conditions which caused warscultural isolation, aggression, need for resources, etc--were all promoted by the fervid commitment of the world's great powers to achieve the ultimate wargasm. Now we can concern ourselves with the underlying problems of famine, disease, poverty, ignorance and, yes, stupidity. At the same time, we can take some perverted satisfaction in knowing that every dollar spent on defense nets us five dollars' worth of ill will and suspicion abroad [60] if it goes to support not democratically elected leaders but corrupt, abusive dictators [61].

For the costly generation of ill-will abroad, however, nothing matches America's commitment to Israel [62]. With zealous Zionists so powerfully entrenched in our media and government, our political leaders are clearly unable to contemplate let alone effect a Mid-Eastern policy which would be so manifestly in the country's best interest: let Israel go its own way while we cozy up to the oil-rich Muslim countries in the area. Of course, it is all but politically suicidal heresy even to hint at suggesting the possibility that we perhaps might one day consider thinking about maybe basing our foreign policy on something like reason and sanity.

That sanity has been warped somewhat by $9 / 11$. From the fall of the Berlin Wall [63] to that fateful day, we had about twelve years to deal open-mindedly with events in something like an objective, if pro-Israeli, manner. Just as we had once viewed everything, overall through a red prism, now we dealt with events in the context of the war on terror(ism) [64] and, in the days of Putin and Trump, seem to be sliding back into the qualified insanity of our Cold War mentality. 
Defense: Unfortunately, in any context, one way to spell "Sanity" is S-T-U-P-I-D-I-T-Y, because it is this which provides us an escape from the incredible world we have constructed for ourselves. Fortunately, the situation is not so desperate that some fool cannot render it absurd to the point of amusement. In the case of defenseless spending, levity was provided by the Air Force General who described the price tag of $\$ 7,622$ for a 10 -cup coffee maker as "Reasonable"! [65]. This is the kind of reason which brings comic if not financial relief to beleaguered taxpayers who never did find out what price the General would have considered "Unreasonable": $\$ 10,000$ ? $\$ 100,000$ ? Of course, anyone who believes $\$ 7,000$ is a reasonable price for a coffeepot should not be serving in Air Force Procurement: he should out there selling coffeepots.

As whistle blowers have discovered to their dismay, the prime concern of those in Waste Management seems to be to see that it continues. For a circuit breaker that John Q. Citizen could buy for $\$ 3.64$, the Air Force paid $\$ 2,543$, and the navy laid out $\$ 740$ for a toilet seat [66]. An hexagonal nut which cost 13 cents at the local hard-ware store was purchased by pentagonal nuts for $\$ 2,043-$ a markup of only $1,500,000 \%$ ! After repeated warnings of serious, potentially widespread criminality and accumulating evidence of gross misconduct [67]. Secretary of Expense Weinberger initiated disciplinary actions against the approver of an eleven part \$659 ashtray. If relieving the officer of command had a sobering effect on the 400,000 bureaucrats entrenched in the Pentagon's procurement offices, it did not last long. Known then for buying $\$ 700$ toilet seats and $\$ 435$ hammers [68], the Pentagon wasted $\$ 100$ million on airline tickets from 1997-2002 because weak internal controls led to millions being squandered on tickets that went unused and not refunded and millions more where the Department of Defense paid travelers for improper and potentially fraudulent claims [69].

If those in Military Waste Management in the late 20th Century were committed to see that it continued, they were incredibly successful. The GAO, in Dec., 2008, reported waste and specifically cited the Navy for keeping an average of $\$ 7.5$ billion worth of spare parts and other goods it does not need-exceeding the Navy's requirements by about $40 \%$ every year because of poor planning and management $t^{1}$. According to a GOA report, the Navy failed to heed repeated warning since 2001 about longstanding problems with inventory mismanagement, and although most of the surplus inventory could be used in the future, $28 \%$ could never be used at all.

${ }^{\prime}$ This kind of corruption has a venerable tradition. In New York in the 1860 's, when a dollar was worth $\$ 10$, Boss Tweed had a field day building a courthouse. A furniture dealer received $\$ 180,000$ for three tables and forty chairs. The windows cost $\$ 8,000$ each. A plasterer was paid $\$ 500,000$ and then another million to repair the damage he had done. One man did $\$ 800,000$ worth of carpentry. Also on the payroll were several dead men. (Hershkowitz. 112118. Roy Morris. 100.) Originally budgeted at $\$ 250,000$ in 1858 , it remained unfinished in 1871 at a cost of $\$ 13$ million. (Fukuyama. 2014. p. 147.) Altogether, he stole the 2010 equivalent of $\$ 8$ billion.
Not surprisingly, the report states that Navy mismanagers are not held accountable for cost inefficiency, which encourages them to rack up billions of dollars in excess inventory [70]. Some of these have consequently devoted themselves to expanding the Defense Department's definition of "Procurer" to cover someone who overcharges an anonymous party (i.e., the taxpayer) for something more than just the traditional screw. That "Something more" included a $\$ 43$ million gas station built by the Department of Defense in Afghanistan from 2011 to 2014. No explanation was given for why it was 140 times more expensive than a similar station constructed in neighboring Pakistan [71].

One civil servant who refused to play ball and accept delivery of some meat which was not up to specs was grudgingly acknowledged by Boss Tweed as "The only honest man in my administration". He was Leonard R. Welles, my great-grandfather. Having been betrayed by both Democrats and Republicans, he committed suicide in 1898. JFW;

As bad as the military was, it was just typical of government in general as revealed by the Grace Commission report of 1984. Calling the federal government "The worst run enterprise in America", the report itemized more that 2,700 examples of poor management and idiotic waste. For example, the Department of Health and Human Services paid Medicare benefits to more than 8,000 dead people. The Government Printing Office wasted $\$ 96$ million mailing publications to incorrect addresses, and the justice Department failed to deposit seized drug money in interest bearing accounts [72]. And yet we increasingly turned to the government to run our lives.

Sad to say, the new century brought nothing new-just continuity-to the field of governmental mismanagement. Although the Justice Department pales when compared to the pros at waste and mismanagement at the Defense Department, it shows the ability of gifted tyros. Cynthia Schnedar, the Department's acting inspector general, exposed wasteful or extravagant spending at conferences which featured costly meals and refreshments. These included Beef Wellington hours d' oeuvres at $\$ 7.32$ per serving and coffee for $\$ 8.24$ per cup, which could be used to wash down huge \$16 muffins and $\$ 10$ cookies [73].

All that is chickenfeed compared to a report by Wartime Contracting Commission which cited major problems in how tens of billions of dollars were misspent in the Iraq and Afghan wars. Specifically mentioned were poor management, weak oversight and a failure to learn from mistakes [74]-a veritable operational definition of stupidity. With so much money to be thrown around, there was no particular incentive to disperse it prudently, so, for lack of ethics, almost $\$ 9$ billion of $\$ 30$ billion disappeared [75]. To complete the picture, whistle blowers who have reported corruption in Iraq have been vilified, demoted, fired or worse [76] for committing the greatest psychosocial sin of them all-telling the truth. 
Deserving special mention in this context is Halliburton-a company formerly run by former Vice-President Dick Cheney. While in office, he maintained his financial connections with the organization, which is at best sloppy and at worst corrupt. However, if it is sloppy, it is oddly sloppy to its own advantage to the tune of billions [77]. (In this case, the whistle blower was one Bunnatine Greenhouse, who was ostracized for righteously asserting that army contracts should be awarded competitively rather than just handed to insiders) [78].

Continuing this theme of waste (on hardware) but changing the focus of mismanagement (of finances) to the field of human software, we find ourselves at sea reading a memo written in the early 1990's by commander of the Navy's surface Atlantic fleet Vice Admiral Joseph S. Donnell. It characterized lesbian ${ }^{\mathrm{m}}$ sailors as "Hard-working, career-oriented, willing to put in long hours on the job and among the command's top performers". One might think that characterization would serve as a reason for recruiting lesbians into the Navy, but who ever said the Navy was reasonable? The document concluded that lesbians should be rooted out of the service, and if there is something counterproductive in this inconsistency, it is at least consistent with the reigning square Pentagon policy, which maintained that homosexuality was incompatible with military service. The Department of Defense initially suppressed these reports and then dismissed them as unresponsive to the original research request, which was to confirm the reigning schema-the demonstrably fallacious but prevalent notion that the presence of homosexuals was detrimental to military efficiency [79].

\section{Environment}

If the defense establishment policy toward efficient and productive gays is hostile and costly [80], the relationship of America to its natural environment is parasitic if not suicidal. However, we have surprisingly few illusions about ourselves being anything but exploiters, as we simultaneously rape, strangle and poison our life support system. Eventually, such behavior will limit our development, and we are actually hastening that day in that we have elevated exploitation to something of a cultural virtue.

While struggles in the fields of politics and social relations dominated the postwar consciousness, there gradually grew in the background an awareness of the ominous strain the burgeoning human population is putting on the world's limited resources. Earth Days notwithstanding, this awareness remains largely the property of environmentalists [81] while political power remains in the hands of industrialists who are willing victims of the neurotic paradox. In the pursuit of

${ }^{m}$ Ca 370 BC the Greeks formed a Sacred Band of homosexual couples which earned a fearsome reputation for courage in battle-the operative principle being that neither partner would want to disgrace himself in front of the other As for women in combat, we would do well to honor Margaret Mead's (1968) advice against permitting it because "They are too fierce". [I prefer "Vicious", but we are stuck with "Fierce". JFW. immediate profits, they are dedicated to the irresponsible exploitation of nature's resources and seem determined to top all the stupidity of all ages past combined with a grandiose display of pollution and destruction of the natural world that supports them. To this end, they have thus far succeeded in keeping the government officials who should be monitoring their nefarious activities happily mired down in their own self-constructed restrictive rules, regulations and red tape.

With industry dedicated to the immediate ravaging of the environment, some kind of international birth control policy limiting the quantity of human life must be implemented if any kind of quality of life is to be sustained over the long haul. For what it is worth, which is not much, the Catholic Church's position on the population problem is consistent with the idea that the miracle of the loaves and fishes can be endlessly repeated [82]. For skeptics, another non-growth strategy is very much in order if not much in evidence.

One strategy that has to go is the obsolete growth and development syndrome [83]. With the earth's resources already apparently stretched to the limit, we simply cannot sustain continued growth of the human population [84], particularly if it is bent on maintaining the current standard of living while wrecking its support system, as it currently is. However, a new philosophy of self-limitations is going to be difficult to formulate, could not be imposed on an unenlightened public and will probably be accepted only after we finally become ashamed of how much enduring misery we can create and the world can maintain-or maybe when it ceases to be perceived as profitable. In no country is philosophy less esteemed as Americans are committed to practicality, preferring trial and error to logic. They embrace if anything, it is the pragmatism of William James, who eschewed monism-the view that everything can be understood from one perspective. If an American stood for anything philosophical, it was being against ideology, unless it happened to be a derivative of Calvinism [85].

The greatest stupidity of all is that we have made our own Calvinistic plight difficult and are making it impossible with overpopulation, pollution and the exploitation of nonrenewable resources. There are some encouraging signs that these problems are finally being recognized as such by people in positions of power, although too little is being done about them. Thus, a stupid person has an advantage in coping with this world over one who tries to understand it logically, as it is a world of compromises, trade-offs and shabby political charades pulled off by self-seeking hacks using ideas and abusing ideals to suit their seedy needs and sordid purposes. The surprise is not that it does not make any sense but that anyone with any brains ever believed it could.

There are two factors which are crucial to the systematic desecration of the environment: 1.) the organization and mobilization of people for the task, and 2.) the development 
of machinery to facilitate the process. Our population is well suited in both quantity and quality to wrecking the environment in that there are too many of us committed to a standard of living beyond the carrying capacity of God-that is, to a standard which is attainable for the entire population for only a limited period of time [86]. In addition, there is specialization and division of labor in our attack on the environment: those not actively engaged in ravaging the land usually devote their energies to polluting the air and water. All this is done in the name of profit and for the sake of more bigger and costlier possessions for as many people as possible. Sadly, the ultimate limits for population growth will be determined not by reasoned planning but by the efficiency with which we can poison our support system and convert our urban centers into behavioral sewers.

To accelerate this process of social suicide, we have turned to machines and computers. The guiding maxim is that the world must be made safe for technology. The worst part of this trend is not that we are ever more efficient at wrecking the environment but that we are bent on creating a world in which machines rather than people can thrive. To the extent that we become robots, we will fit into the world we are creating. However, our success in adapting will be a function of our willingness to renounce the differences between humanity and cybernity. Civilization has developed to the mutually interactive point that we now have to become less human as we adapt to the self-effacing technology which creates us.

\section{Art}

The message of contemporary America is clear: people are out. They are obsolete, except to the extent they serve computers. The tradition of humans adapting to their tools has reached the pointless point that all phenomena (like feelings) which cannot be quantified for computers have been rendered irrelevant by them. In a sense, technology and modern art are equal in being devoid of human emotion-but, still, some art is better than it looks.

People and feelings were distorted and abstracted out of art early in the twentieth century. As artists sought novelty of expression for its own sake, emotional impoverishment came to reign in a world of any and all contrived means devoted to no particular end [87]. Just as modern composers labor to reduce if not eliminate the distinction between music and noise [88],-to the decided detriment of noise-by subconsciously representing random chance in space, modern artists aptly express the vacant extreme of total irrelevance and meaninglessness that civilization has achieved. As a triumph of technique masking the absence of substance, it represents the ultimate victory of public relations in modern life. As an exercise in cognitive and spiritual futility, contemporary, nonobjective [89] cum abstract go drip, irresponsible art is a wakeup call reflecting the basic spiritual emptiness and moral void of emotionally bankrupt Western institutions and life ${ }^{\mathrm{n}}$.

\section{Education}

This bankruptcy is further demonstrated by the way many serious social problems develop unexpectedly, often resulting from neglect, ignorance and wishful thinking. For example, when the government insisted on busing school children in and out of cities, about $30 \%$ of the white suburban school population dropped out of the public school system and went to private schools. It is certainly to be hoped that the equalization of academic training achieved by busing between urbs and suburbs compensates for the effects of discrimination on the students, and to the extent that the goal of integration was achieved, liberals must have been gratified [90]. However, the discriminatory method applied was counter-productive in that it drove off many of the students counted on to serve as so many "Racial units" in the bus drive to substitute one bunch of equal kids for another. For example, in Boston, in the twenty year period between the early 1970's and 1990's, white enrollment in the public school system dropped 40\% [91]. As a desegregation expert noted in 1980, "There are simply not enough white children to go around" [92]. Apparently, the goal of public educators is to convert diverse pupils into equally illiterate graduates [93].

The contemporary mania for social equality might be laudable were not egalitarians so passionately committed to leveling downward [94]. Formal educational systems cannot be expected to improve society because schools are now primarily social institutions designed to bring young people together in an integrated setting. The commitment to academics is not dead, but it is distinctly second to our efforts to create equal citizens. Naturally, this makes any gesture toward excellence awkwardly out of place.

In addition to our egalitarian bent, a commitment to illusion rather than achievement contributed to the deterioration of academic standards over the past few decades. At the same time that we were inflating our currency to create the illusion that we were getting more than we earned, we were inflating diplomas [95] to create the illusion that students were accomplishing more than they learned. Of course, cheapening grades does nothing for the learning process, but it makes a lot of students feel good about themselves. The long-term result is that bloated grades and diplomas cease to be of value to anyone, but that is irrelevant to those who live in a world increasingly determined by PC symbols rather than substance.

Sad to say, not everyone loses equally. The real, major losers are the students who need to develop skills for coping in the job market because those who need some extra help are the ones who are most likely to get inflated grades rather than more, better training. Worse yet, those who aspire to escape the inner cities may have to attend schools which are physically the oldest and in which teacher turnover is the highest.

${ }^{n}$ An exercise somehow enhanced in America by the breakthrough discovery, in the mid-1950's, that the canvass, like the world of the internet, was flat. (Rosenberg.) 
Although some may think that education could be the salvation of the disenfranchised, in this regard, blacks in New York City certainly do not have much to look forward to from or in the Establishment. As Dr. Donna Shalala, when president of Hunter College pointed out, the New York public schools had a dropout rate of $42 \%$ in 1984 , with relatively few blacks ${ }^{\circ}$ graduating and being integrated into the system. Thus, many are becoming alienated and learning to live in what will amount to a foreign country in their own land. As might have been expected, New York City officials treated Dr. Shalala as a traitor to the cause of education for pointing out that the cause was failing, which it obviously was [96].

The factors contributing to this failure of the urban educational system are, of course, legion. The school facilities in the inner cities are usually old and decrepit. Teacher turnover is high, with few teachers staying in such schools for more than five years and some children having as many as four teachers a year. Community support is minimal and distractions maximal. The net result is that those who need more help are getting less, so many unfortunately leave school, sooner than later, inadequately prepared to find decent employment or continue their education [97].

The fact of life in inner city schools is that truancy is excessive, with teachers being privately relieved when problem students are absent. In their early teens, children begin leaving school to join the ranks of the unemployed and eke out a living on odd jobs and crime. They have not yet been organized into any large scale criminal or political movement, but if and when they ever are, the failure of public education will become obvious even to those responsible for it [98].

Whether this ever happens or not, we remain in danger of losing a generation of young urbanites largely because they have no formal education. They have no intellectual skills, no guidance and, worst of all, no hope. They know no one who has successfully managed to get out of the inner city [99], and if they have learned anything in school, it is that they cannot make it in the system-a frustrating awareness that contributed to the hostility to established authorities manifested in the urban riots of the 1960's. If they are motivated to do anything, it is to get up and out any way they can, which in far too many cases leads them to reform schools, psychiatric clinics and much too often eventually to prisons [100].

Within the system, the problem of measuring learning ability has always been one of testing and, more specifically, one of developing an unbiased test. Generally, what might be referred to as the standard IQ test was soundly criticized as a middle class device for intellectual discrimination against minority groups that do not do well on them: or, in Marxian terms, intellectual competence is a device of bourgeois suppression [101]. Such criticism formed the basis for a court

'Actually she is reported to have said "No blacks" but that is suspectperhaps/probably a case of inaccurate reporting. decision in 1980 which declared it unconstitutional to use intelligence tests to place black children in classes for the retarded. The ruling stated: "An unbiased test that measures ability or potential should yield the same pattern of scores when administered to different groups of people" [102]. And it would, if ability were equally distributed among different groups, but that is just an assumption and, given the unequal distribution of educational resources, an unlikely reality. If a test provides results which contradict this assumption, that is hardly a reason to throw out the test but rather to check both the test and the assumption.

Further, in developing analytical stupidity and frustrating artistic ability, American educational institutions are highly one-sided in that they concentrate intensely on the verbal left hemisphere of the brain [103]. As befitting a highly industrialized society, the abilities to focus on fantasies, ignore facts, misapply rules and massage data to confirm preconceived illusions are all cultivated in our classrooms and labs. Rather than being well springs of creativity, our schools and colleges are devoted to propagating acceptable answers to established questions. In the sterility of academics, everything is reduced to corporate reason while being rendered irrelevant. Above all, reason is out [104].

In the world at large, leaders are often the worst students and quite reluctant to learn about and understand what they are doing. Mental stagnation at upper levels of government is as common as is supposed, since rulers usually strive to maintain intact the schemas with which they started. No less of a pundit than Henry Kissinger noted that leaders of state do not learn beyond their convictions [105]. When confronting a problem, they seek information that will make it seem similar to previous situations [106]. Their experiences may confirm beliefs or lead to minor adjustments of policy, but the mighty are ill disposed to learn they are wrong about anything. In contrast to our victory over Iraq in 1991, our government backed losers in China, Cuba, Vietnam and Iran [107] in its commitment to demonstrate America's inability to profit from its losses for the sake of being itself and providing yet another example of a society corrupted from the top down.

Identity: Maintaining "Identity" can really stupefying, as demonstrated in Louisiana in the 1960's when officials were proceeding to integrate the schools with all deliberate sloth [108]. A proposal that integration be started in kindergarten and then proceed one grade per year for twelve years was rejected for the worst of all possible reasons-because it would work. The good ol' boys in power did not want a plan that would work; they wanted to be themselves. The only problem with "Being yourself" is that it can create difficulty for the people who think we should all do what is efficient and right.

Expanding beyond segregated schools to the racially bigoted southern society in general, the presumption of systemic dissonance was expressed in the pithy observation: 
"They're all torn apart inside. They try to make you believe that things that are not all right are fine, and they sweat as they search for the words to do it with..." [109]. However, bigots may not be torn up inside. They can be quite happy being themselves and get agitated only when some problem person from outside points out the discrepancy between what Jesus Christ said and they themselves do.

In an entirely different context, Frank Serpico was just such a problem person. He wanted to be a good policeman, which to him meant enforcing the law. This made him something of an anomaly in New York City during the mid-1960's. Officer Serpico found that bribery, graft and extortion were such common forms of police behavior that cop after cop was encouraged by the prevailing culture to go on the take. In a department awash in its own arrogance, he made a career of making enemies among his colleagues by the unheard of practice of policing the police. Naturally, he became known as a trouble maker when he insisted on standing on principle and forcing awareness of the existing, cognitively dissonant conflict between official standards and actual police conduct. Although the department ignored him as best it could for as long as possible, his efforts were not totally in vain. He finally went to the newspapers and generated enough publicity to effect some temporary reforms [110].

Is it not stupid that-cognitive dissonance aside-Serpico had to fight against the system just to get it to live up to its own stated if roundly ignored standards. He was peculiarly obsessed with the notion that the government should obey its own laws. He discovered the hard way that the Nixonian doctrine that officials are above the law is rather common in America, and this insight and his integrity were lost to the nation when his career was ended by a serious wound received when his colleagues deliberately left him out on a limb during a drug raid: he then went into self-assumed exile in Europe [111].

In this vein, a person of integrity in a world of cons and scams really can be annoying. An Hispanic, with the unlikely name of Henry Harrison, proved this point when he became a fly in the ointment of integration by insisting on doing what was right. In 1984, Mr. Harrison was a fireman in Miami when he asked his superiors to remove his name from a promotion list so that he would not advance over colleagues he considered more deserving. His chief expressed shock and confusion over Harrison's reluctance to take advantage of Affirmative Action guidelines to move ahead of fellow workers who had scored higher in the qualification process [112]. From Harrison's standpoint, his decision might be considered stupid, in that he was sacrificing his own advancement for the sake of creating a more efficient fire department. The ironic point is that he had to do this in the face of regulations which were designed to promote people according to qualities irrelevant to job performance. How nice it might be if advancement of individuals within a group and improvement of group efficiency went together rather than being at odds with each other.

As vexing as Serpico's acts of conscience were for the establishment, Mr. Harrison's was even more so because he showed that simply obeying or abiding by the laws and rules is not enough if those regulations themselves are unconscionable. Beyond commandments inscribed in stone, Constitutions written on parchment and laws compiled in books, there is a spirit which animates a culture. It is this which provides an ethical and moral basis for judging the stupidity of official schemas. The irony inherent in culture is that religious beliefs are so often at odds with behavioral norms.

This problem is particularly confusing for Americans, because, more than any other nation on earth, we are a hodgepodge descended from Europeans, Africans, Asians and native Americans. We are Christians, Jews and atheists. We are capitalists, fascists, socialists and anarchists. We are a dynamic conflict of many competing interests all bent on getting more than their fair share of the national pie rater than making the pie bigger. No student of society, government or economics can look upon us without a sense of bewildered amazement. If life is a temporary state of dynamically imbalanced conditions, and it is, America is certainly very much alive, but that such a chaos of conflicting schemas can flourish is due in large part to the stupidity of Americans who resolutely refuse to perceive inconsistencies where they exist. Only those who are stupid enough to try to understand what is going on find that it could not possibly "Make sense". Oddly, there is both security and danger in the incomprehensibility of the American experience: we are too complex to be wrecked by planning, but we have lost control of our own fate.

In a similar vein, the inability of minority group members to match up even to "Special" standards is sometimes strikingly displayed to the embarrassment of all. Such was the case in New York City in September, 1984, when only 1.6\% of black candidates passed a police sergeant's exam which had been designed to favor minorities. The explanation for the poor showing on the exam was that, in its effort to find or create sergeants among minority groups, the department apparently allowed many totally unqualified candidates to take the test [113]. This commitment to integration thus ended up with everyone getting a black eye-officials, who were obviously willing to sacrifice quality on the Procrustean bed of equality, and black patrolmen, who performed so badly on a test doctored to make them look good.

Perhaps because government officials think they can decree by fiat that test results and promotional procedures must confirm the liberal ideal that all groups are created equal in ability, society is failing to provide minority group members with the skills they need to compete on an even footing with everyone else but nevertheless granting them undeserved positions of authority. The tragedy is that if America is unwilling 
to pay the immediate price for improving public education, everyone will pay eventually, directly or indirectly [114]. For those denied a decent education, it means wasted lives or being showcased in positions beyond their competence. For society in general, it means at least inefficiency and probably an increase in crime and an added burden on social services. Those who think they are immune to these problems are deceiving themselves about being above and beyond dealing with incompetent bureaucrats and the economic costs of $\$ 1$ billion a year [115] for crime prevention programs, police protection and prisons.

It is noteworthy that the ideologies of many groups of economically disenfranchised Americans do not represent efforts on their part to understand their condition cognitively so much as to cope with it emotionally, and they range from theories of black supremacy to perversions of civil rights. In this latter context, one of the more popular cliches is "Minority rights" (i.e., black rights, women's rights, etc.), which implies that members of minority groups have legal rights others do not and contrary to an earlier ruling by the Supreme Court are now not just mere citizens but special favorites of the law [116]. In fact, "Civil rights" has come to mean "Integration", and if this end is laudable and desirable, the means of requiring racial and sexual discrimination to attain it are not, even according to the professed standards and values espoused by liberals. However, as long as the government tries to impose equality upon society by accepting mere competence as a substitute for excellence, everyone but the incompetent will lose as institutions become less efficient.

The basic problem of America is one of breadth without depth. With so much to draw on in terms of both human and natural resources, national character was shaped by pragmatic, short-term policies geared to specific and often isolated situations. So often, as both the New Dealers and Watergate gang found, solutions became problems: the reaction to bad business and bad politics was bad government. The only thing we do not have is an American way of wrecking the country. American stupidity is creative in that there seems to be no limit on the ways we can find to take a bad situation and make it worse.

Ironically, the national commitment to our own well-being has become a fatal break preventing us from achieving the progress politicians are always proclaiming or promising. Progress is a matter of passing beyond an existing state of affairs [117]. In a material sense, this means developing a higher standard of living, and this we have achieved but at the price of having it shape our morality. Attaining the physical comforts of material prosperity has made us both proud and uneasy, but there has been no progress toward peace of mind. Behind our pride exists the gnawing realization that immediate compassion and concern for the down-trodden and dispossessed cannot be converted into legislative programs of any significant long-term success. Slums, apathy, ignorance and stupidity remain as real and debilitating as ever before because we have made no enduring commitment to help others less fortunate then ourselves to improve their lives. In human terms, America hardly represents progress much less promise for the future.

\section{References}

1. Schlesinger Jr. A. The Cycles of American History. Houghton Mifflin; Boston, MA. 51. 1986.

2. Ibid. 53 .

3. Roosevelt BJ. The Soldier of Freedom. Harcourt, Brace, Janonovich New York. 1970. 216. Phillips, C. 1975. The 1940s: Decade of Triumph and Trouble. Macmillan; New York. 110. King, C. Gods of the Upper Air. Doubleday; New York. 2019. 322-325..

4. Irons P. Justice at War. Oxford; New York. 1983. 59. A thought echoed by Walter Lippman. The Fifth Column on the Coast. Washington Post. 1942; 9.

5. O'Reilly B, Dugard M. Killing the Rising Sun. Henry Holt; New York. 2016. 62fn. The worst decision was Dred Scott (1857)-that blacks are not citizens, and the second worst was Plessey vs. Ferguson (1896)separate can be equal -as if the act of separation was of no significance.

6. Goodwin D. No Ordinary Time. Simon \& Schuster; New York. 1994 296. Stop a moment and break that down in your mind. They were not looking for proof of criminal activity. Nor were they looking for a suggestion of criminal activity. They were looking for anything the MIGHT suggest criminal activity.

7. Stone O, Kuznick P. The Untold History of the United States. Gallery Books; New York. 2012; 152

8. Stone G. Perilous Times. Norton; New York. 2014; 296

9. Breye, S. (Supreme Court Justice) The Court and the World. Vintage Books; New York. 2016. 18. Lincoln and FDR both chose the Union/ country over the Constitution and so, probably, will any president given that choice.

10. Schlesinger Jr. A. The Imperial Presidency. Houghton Mifflin; Boston MA. 116.1973

11. Turley J. The Reason We're No Longer the Land of the Free. Washington Post. 2012.

12. Murphy F Jus. Concurring opinion in Hirabayashi v. United States. 1943.

13. Murphy originally wrote his opinion as a dissent but was persuaded by Justice Frankfurter to cast it as a concurring opinion. Fairly put, it is a negative concurrence.

14. Black Jus H. Korematsu v. United States. 323 US2 14, 233. The explanation that the internees were taken into custody for protection from their neighbors and fellow citizens is too intellectually insulting to be considered. 1944.

15. Lloyd A, Cantril H. The Political Beliefs of Americans. New Brunswick, NJ. 1967. 33.

16. Bitsoli S. Memo to the New Court: Let's Avoid 'Stupid' Law. TCR In Depth. 2018

17. Bidinotto R. Crime and Consequences. Foundation for Economic Education; Irvington-on-Hudson, NY. 1989.

18. McWilliams P. Ain't Nobody's Business If You Do. Prelude Press; Los Angeles, CA. 1993; 227.

19. Mann C. 1493. Vintage Books; New York. 172. 2012. 
20. Ferguson N. The Ascent of Money. Penguin Press; New York. 29. 2008

21. Hammond P. An Introduction to Cultural and Social Anthropology. 2nd ed. Macmillan; New York. 170. 1978.

22. The New York Times. Nov. 4, 2007. Playing Games with Toy Safety.

23. Meehan J. America's Bumbling Bankers: Ripe for a New Fiasco. Business Week; 86-87. Psychologically, this was rather "interesting" in that $\$ 1$ trillion which bankers thought existed did not. (Sass. 366.) Sharing the misery, the global stock market lost $\$ 30$ trillion-that is $\$ 30,000,000$ 000,000. (Ibid. 367.) It appears that Americans are addicted to dollars that do not exist. (Ibid. 381.) For anyone who wonders what is gong to happen, the answer is, the dollar will become worthless. Anyone who can corner the market on "0's" will clean up. (23. Hammond. op. cit.1992.

24. Kilborn P. "Race Norming" tests become a fiery issue. The New York Times; The Week in Review. 5. 1991.

25. Hammond. op. cit. 193.

26. Raspberry W. The Washington Post. 1984.

27. Harrison H. "The Negro Conservative: Christianity Still Enslaves the Minds of Those Whose Bodies It Has Long Held Bound". 1914. Quoted on page 438 of Hecht, J. Doubt: A History. HarperOne; New York. 2003.

28. Hammond. op. cit. 342.

29. Johnson G. "The Suppliant" Quoted on page 294 of Hecht. op. cit.

30. Walker P. Charity begins at home. In Duncan, R. and Weston-Smith, M (eds.) The Encyclopedia of Delusions. Wallaby; New York. 1979; 226.

31. Steele S. The Content of Our Character. HarperCollins; New York. 1990. Chap. 7. Lester, R. Antibias Regulation of Universities. McGrawHill; New York. 1974. 66. Levin, M. Men in Black: How the Supreme Court is Destroying America. Regnery; Washington, DC. Chap 6. 2005.

32. Kennedy A Jus. Fisher vs. University of Texas. 2016.

33. Brown Justice H. Plessy v. Ferguson. 163 U.S. 537. 1896.

34. Griggs v. Duke Power. 1971. United Steelworkers v. Weber. 1979 Fullilove v. Klutznick. 1980. Hayward, S. 2009. The Age of Reagan: The Conservative Counter-revolution. Crown; New York. 361.

35. Kennedy, Pres. J. Mar. 1961. Executive Order 10925. Johnson, Pres. L. Sept. 1965. Executive Order 11246.

36. Bradley, Jus. J. Oct. 15, 1883. United States v. Singleton. 109 U.S. 3.

37. Toobin J. The Nine. Doubleday; NY. 210-211. 2007.

38. Ramirez B. Berry M. Quoted on page 63 of Toward an Understanding of Stotts. U.S. Commission on Civil Rights. Clearing house Publications 85. 1985.

39. Hayward S. The Age of Reagan: The Fall of the Old Liberal Order. Three Rivers Press; New York. 354. 2001.

40. McGovern G. Cited in Radosh R. Divided They Fall: The Demise of the Democratic Party, 1964-1996. The Free Press; New York. 121. 1996.

41. Reynolds W. Cited on page 223 of Hayward, S. 2009. op. cit. 1970.

42. Thomas J. The New Outcast? Sun-Sentinel. Fort Lauderdale, FL. 1994

43. Roberts J. Chief Justice. Statement at the Supreme Court. 2007.

44. Breyer S Justice. Statement at the Supreme Court. 2007.

45. Evans-Pritchard A. The Secret Life of Bill Clinton: The Unreported Stories. Regnery; Washington, DC. 336. 1997.

46. Quotation from the Christian Union. 1875. 442.
47. Purcell $\mathrm{H}$. The fallacy of environmentalism. In Duncan and WestonSmith. op. cit. 92.

48. Newsweek; CXI, \#26, 48-55. Taking Offense. 1990.

49. Pitkin W. A Short Introduction to the History of Human Stupidity. Simon and Schuster; New York. 516. 1932.

50. Nourse V. In Reckless Hands. Norton; NY. 2008.

51. Schlesinger Jr. A. Robert Kennedy and His Times. Houghton Mifflin; Boston, MA. 451. 1978.

52. Carter. President J. Commencement address at Notre Dame University. 1977.

53. Schlesinger Jr. A. The Cycles of American History. Houghton Mifflin; Boston, MA. 55. As bad as we were in misperceiving the USSR, leaders in the Kremlin were even worse in misjudging us as descendants of original sinners who divided Eden into plots of private property. Both sides need programs of cultural exchange and students of history so that dynamics might carry them beyond their set-piece beliefs toward understanding. 1986.

54. Stern S. Remembering Pinochet's Chile. 2006. Duke University Press; Durham, NC. 22. In addition, U.S. supported operatives in South America put the worst totalitarian regimes to shame with their kidnaping, torturing and murdering of political (i.e., leftist) opponents. (Hancock. 316.) 2006.

55. Olds R. Undersecretary of State. Quoted on p. 327 of Hancock, L. Shadow Warfare. Counterpoint; Berkeley, CA. 2014. 1927.

56. Hayter W. In The Cold War edited by E. Luard. London. 1964.

57. Hayward S. op. cit. 284. The lesson learned re: Munich was remisapplied by 43 when rationalizing the totally unjustified invasion of Iraq in 2003-to eliminate the alleged threat Saddam Hussein did not pose to the USA. (Eichenwald. 497.)

58. Clarke R. Your Government Failed You. HarperCollins; New York. $2008 ; 142$

59. Tuchman. op. cit. 8.

60. Pitkin. op. cit. 426.

61. Woods T. 33 Questions About American History. Three Rivers Press; New York. Question 29. 2007.

62. Bamford J. A Pretext for War. Anchor; New York. 138-139; 407. Bodansky, Y. 2004. The Secret History of the Iraq War. Regan Books; New York. 2004; 35: 275-276.

63. Engel J. George H. W. Bush in The Presidents by B. Lamb, S. Swain, and C-Span. Public Affairs; New York. 2019. 244. The fall of the wall was an incredible error. An East-German spokesman read the wrong announcement on TV, giving people the impression they could cross over to the West. The guards at the wall decided not to mow down their compatriots, so the wall came down.

64. Scahill, J. Dirty Wars. Nation Books; New York. 193. 2013.

65. The New York Times (Large Type Weekly). Sept. 24, 1984. 13 Margasak, L. Feb. 22, 2000. Pentagon can't shake its wasteful spending. Associated Press. (Specifically, Sun-Sentinel. Ft. Lauderdale, FL. 4A.)

66. Speakes L. Speaking Out. Scribner's; NY. 79. 1988.

67. Johnson H. Sleepwalking Through History. Anchor; NY. 1991; 177-178.

68. Fairhill J. "The Case for the $\$ 435$ Hammer". Washington Monthly. $1987 ; 47-52$.

69. Allen V. Pentagon Wasted $\$ 100$ Million on Unused Air Tickets. Reuters. America On Line. 2004 
70. Kelley M. GAO details billions in Navy excess. USA TODAY. 7A. 2008.

71. Ali I. 2:05 PM. Pentagon spends $\$ 43$ million to build Afghanistan gas station. Reuters. America On Line. 2015.

72. Hayward S. op. cit. 340. (Close paraphrase.)

73. Merkon J. A \$16 Muffin? Washington Post/ AOL. 20110

74. Lardner R AP. Major problems found in Iraq, Afghan war spending. America On Line; Money and Finance. 2009.

75. Schmitt E, Thompson G. \$6 Billion in Contracts Reviewed, Pentagon Says. The New York Times. 2007.

76. Hastings D. Americans Who Report Iraq Corruption Pay a Price. International Herald Tribune. 2007.

77. Kelley M. USA Today. Largest Iraq Contract Rife with Errors. 2007.

78. Burger T. Zagorin A. Beyond the Call of Duty. Time. 2018; 2004.

79. Gross J. Navy Is Urged to Root Out Lesbians Despite Abilities. The New York Times. 24. 1990.

80. Schmitt E. Military's Anti-Gay Rule Is Costly, a Report Says. The New York Times. 6. For those who care, the Bible is explicitly anti-gay. Leviticus: 18, 22. (620-332 B.C. A prolonged gestation.) 1992.

81. Read R. Is there still a role for the state? (Mr. Read was running for European Parliament, and his comment had global implications.)

82. Pitkin. op cit. 2008; 512.

83. Hammond. op. cit. 141.

84. Brown L. "State of the World" (World watch's 11th annual report). Quoted in "World may be at biological limit as growth in food supplies slows". Associated Press. (Sun-Sentinel. Fort Lauderdale, FL..) 1994; 10.

85. Schlesinger. op. cit. 52.

86. Erlich P. The Population Bomb. Ballantine; New York. Chap. 1. Pimental, D. May, 1994. Natural resources and an optimum human population. Population and Environment. 1968.

87. Tomlin E. Novelty is the chief aim in art. In Duncan and M. WestonSmith op. cit. 236. Of course, novelty is one possible aim in art. There are others. 1979.

88. Russell G. The Lydian Chromatic Concept of tonal Organization for Improvisation. 27. 1959.

89. Lukach J. Hilla Rebay: In Search of the Sprit in Art. George Braziller: New York. p. 144. (As an absolute aside, the first of the "Non-objectors" reveled in Platonic forms-circles and triangles-as cultural ideals.) 1984

90. Taylor J. Paved With Good Intentions. Carroll \& Graf; New York. 1992.

91. Ribadeneira D, Tye L. Racial Gap Widens in Boston Schools. Boston Globe. 1992.

92. Lindsey R. School Integration Looks More Than Ever Like a Lost Horizon. The New York Times. 1980.
93. Bovard J. Lost Rights. St. Martin's Press; New York. 133. 1994.

94. Purcell. op. cit. 95.

95. Gitlin T. The Sixties: Years of Hope, Days of Rage. Bantam; New York. 431. 1987.

96. Reeves R. Black Americans real foreigners because of school dropouts. Universal Press; Kansas City, MO. (Specifically, this syndicated article appeared on this date in the Sun-Sentinel, Fort Lauderdale, Florida. 14A.) 1984 .

97. Walker. op. cit. 227.

98. Ibid.

99. Rangel C. Quoted in "A summary of views as summit begins". USA Today. Jan. 6, 1994. 6A.

100. Walker. op. cit. 228.

101. Scruton R. Fools, Frauds and Firebrands. Bloomsbury; New York. 2015. 221.

102. Newsweek. XCV, \#7, 104. Tests: How Good? How Fair? 1980.

103. Ornstein R. The split and the whole brain. Human Nature; 1, 76-83. As neurologist Winston $\mathrm{S}$. Churchill noted, the problem is that the human brain has two hemispheres, only one of which does any work (Churchill. 1930. 331.)-and that leads to crass stupidity. If we could but cultivate our right hemisphere, we would have twice as much stupidity interrelated in artistic ratios. 1978.

104. Jacoby S. 2008/2018. The Age of American Unreason. Pantheon; New York. 30.

105. Kissinger H. The White House Years. Little, Brown; Boston, MA. 1979.

106. Houghton D. The role of analogical reasoning in novel foreign policy situations. British Journal of Political Science. 1996; 26: 523-552.

107. Tuchman. op. cit. 383.

108. Haygood W. Showdown. Knopf; New York. 2015. 5.

109. Waring Judge J. Colliers. 1950.

110. Maas P. Serpico. Viking Press; New York. 1973.

111. Rappe E. The Real Frank Serpico Looks Back. 2010.

112. AOL.

113. Robertson L. The Miami Herald. 1D. 1984.

114. The New York Times. Incompetence in Police. Sept. 14, 1984.

115. Walker. op. cit. p. 228.

116. Jensen M. NBC Nightly News. 1994.

117. Bradley Jus J. United States v. Singleton. 109 U.S. 3. Oct. 15, 1883. California Regents v. Bakke. 1978. 117. Pitkin. op. cit. 272. 